\title{
Paulo Freire: da denúncia da educação bancária ao anúncio de uma pedagogia libertadora
}

Miriam Furlan Brighente*

Peri Mesquida**

DOI: $10.1590 / 0103-7307201607909$

\section{Resumo}

Este artigo procura identificar o sentido da denúncia da educa-

* Pontifícia Universidade ção bancária, realizada por Paulo Freire, e apontar suas implicações para o anúncio de uma educação libertadora sobre o corpo dos educadores. A partir das obras do educador, busca-se discutir, num primeiro momento, a denúncia da educação bancária, e, num segundo momento, o anúncio de uma pedagogia libertadora freireana: problematizadora e conscientizadora. Para a análise interpretativa dos dados, lançou-se mão da hermenêutica Católica do Paraná (PUCPR), Curitiba, PR, Brasil. miriambrighenti@yahoo. com.br

* * Pontifícia Universidade Católica do Paraná (PUCPR), Curitiba, PR, Brasil. mesquida.peri@gmail.com como metodologia de pesquisa em Educação. Como resultado, verificou-se que, quando Freire faz o anúncio de uma pedagogia libertadora, ele não está apenas propondo outra realidade possível, mas, também, está fazendo a denúncia de uma educação opressora, vista como uma negação do corpo na prática pedagógica. Por fim, uma educação libertadora só se efetivará quando o educador/educando oprimido se conscientizar, reconhecendo o opressor hospedado no seu corpo. Será o educador/educando livre, portanto, a partir da práxis e da humanização de si e dos outros.

Palavras-chave: educação bancária, negação do corpo, Pedagogia Libertadora, educação de educadores 


\title{
Paulo Freire: from denunciation of a banking education to the announcement of a liberating pedagogy
}

\begin{abstract}
In this paper, we aim to identify the meaning of the denunciation in the banking education, idealized by Paulo Freire, as well as to point out the implications of a liberating education for the the education of educators. First, the article discusses the denunciation of banking education, as it appears in his work entitled Pedagogy of the Oppressed (2005) and also in his books Pedagogy of Indignation (2000) and Education and Actuality Brazilian (2003). Secondly, this paper discusses the announcement of a liberating pedagogy idealized by Paulo Freire: problematization and critical consciousness, based on theoretical arguments of Paulo Freire, approached in Awareness (2001b), Cultural Action for Freedom (2002a) and Education as the Practice of Freedom (2009). Using hermeneutic as a research methodology, we showthat, when Freire makes the announcement of a liberating pedagogy, he is not only proposing another possible reality, but also he is making the denunciation of an oppressing education, seen as a denial of the body in the pedagogical practice. Finally, a liberating education only will become effective when the oppressed educator-educating become aware, recognizing that the oppressor is been hosted into your own body. They will be free, therefore, from the praxis and their self-humanization and others.
\end{abstract}

Keywords: banking education, denial of body, liberating pedagogy, educators education 


\title{
INTRODUÇÃO
}

É fundamental, inicialmente, deixar claro qual a noção de corpo que perpassa este estudo com base no pensamento de Paulo Freire. 0 educador se refere ao corpo negado como aquele ao qual foi proibida a possibilidade de ser sujeito. Assim, é visto apenas como objeto, como se ao corpo, ao ser, lhe fosse negada a capacidade de compreensão da realidade, da sua apreensão e da sua comunicação (Freire, 2002b, 2005). Portanto, para Freire, pode-se proibir o corpo de ser, negando-o como corpo consciente. É o que ele chama, também, de "interdição do corpo", numa entrevista concedida à Revista Teoria e Debate (1992, n.d.), quando, ao responder uma das perguntas feitas por Mario Sérgio Cortella ${ }^{1}$ e Paulo de Tarso Venceslau ${ }^{2}$, aborda o tema sexualidade e corpo, fazendo uso da expressão "interdição do corpo", como podemos verificar a seguir:

\begin{abstract}
Ninguém vive bem sua sexualidade numa sociedade tão restritiva, tão hipócrita e falseadora de valores; uma sociedade que viveu a experiência trágica da interdição do corpo com repercussões políticas e ideológicas indiscutíveis; uma sociedade que nasceu negando o corpo. ... É preciso viver relativamente bem a sexualidade. Não podemos assumir com êxito pelo menos relativo, a paternidade, a maternidade, o professorado, a política, sem que estejamos mais ou menos em paz com a sexualidade. No fundo ... é uma advertência para que assumamos, tanto quanto possível, o que estamos sendo.
\end{abstract}

Na realidade, Freire não tem um (ou o) conceito de corpo, mas, sim, como vimos na citação anterior, ele deixa transparecer o que entende como corpo. Nesse caso, Freire (1992) observa que a sociedade brasileira vivenciou a experiência do que ele chamou de "violência da interdição do corpo", dentro de uma realidade social que já surgiu rejeitando o seu próprio corpo.

Dessa maneira, neste contexto, realizamos a denúncia da educação bancária, vista como uma negação do corpo do educando. Na realidade, o que Freire denominou “educação bancária”, atualizando a expressão e lhe dando uma conotação moderna e de acordo com a sua visão de mundo, foi levantado pela primeira vez por Lucius Mestrius Plutarchius, nome latino de Plutarco (44-120 da nossa era). Na obra intitulada, na tradução francesa, Sur

1. Na época da entrevista, ele ocupava o cargo de Secretário Municipal de Educação de São Paulo.

2. Durante o período de publicação dessa matéria, ele era membro do Conselho de Redação da revista Teoria $e$ Debate. 
l'éducation des enfants (Oeuvres Morales, Tome, I, 1844, p. 38), encontramos a seguinte expressão do filósofo greco-romano: “O espírito (a cabeça) não é como uma jarra que se enche. Semelhante às matérias combustíveis, ela tem, antes, necessidade de um alimento que o sacie, que aqueça suas faculdades e anime o espírito para a busca da verdade".

Nessa frase, Plutarco resumia para nós, educadores modernos, o que significa educar. Quando nos preocupamos em encher a cabeça dos educandos com conhecimentos, sem levar em conta que eles precisam é de um "alimento" que vivifique as suas faculdades e os encoraje a seguir na direção da pesquisa da “verdade”, estamos apenas enchendo a jarra.

Da mesma forma Johann Heinrich Pestalozzi, na obra Écrits sur la méthode (Vol. III, 2009, p. 160) não considerava o(a) educando(a) como "um vaso vazio que se deve encher", mas como "uma força real, viva, ativa por si mesma que, desde o primeiro momento da sua existência age no sentido de um corpo orgânico sobre seu próprio desenvolvimento". Freire, a rigor, substituiu a jarra de Plutarco e o vaso de Pestalozzi por banco, com o mesmo sentido dado pelos seus antecessores. Esse é o sentido do que Freire chama de "educação bancária".

Com isso, ao denunciarmos a educação bancária, acompanhando Freire, realizamos o anúncio de uma pedagogia libertadora freireana: problematizadora e conscientizadora, para a educação dos educadores. Esse processo de libertação do oprimido, como verificamos com Freire, só é possível por meio da educação, desde que permita a educadores e educandos tomarem consciência da negação do próprio corpo.

Ao longo da história do Brasil, o corpo de homens e mulheres foi negado, seja pelos colonizadores, pelos jesuítas (os primeiros educadores brasileiros), seja pela família ou pela escola. Lembramos que o corpo dos gentios foi sendo interditado quando chegaram os homens brancos à América. Para ilustrar essa reflexão, Freire (2000, p. 73), no livro Pedagogia da indignação, escreve um texto sobre o "Descobrimento da América", refletindo sobre os 500 anos da chegada dos portugueses ao Continente, que permitiu não o "descobrimento" (como os livros de história contam), mas a conquista do corpo e da alma da América, sendo que as mazelas permanecem conosco até os dias de hoje. 0 autor não nega o direito de festejar, mas diz que a homenagem deve ser realizada para aqueles que com coragem lutaram contra o colonizador, que buscaram sua liberdade, quando seus corpos na verdade eram "rasgados" e suas vidas eram "roubadas". E acrescenta: 
0 corpo e a alma da América, o corpo e a alma de seus povos originários, assim como o corpo e a alma dos homens e das mulheres que nasceram no chão americano, filhos e filhas de não importa de que combinações étnicas, o corpo e a alma de mulheres e homens que dizem não à dominação de um Estado sobre o outro, de um sexo sobre 0 outro, de uma classe social sobre a outra, sabem, o corpo e alma dos progressistas e das progressistas, o que representou o processo de expansão européia que trazia em si as limitações que nos eram impostas (p. 74).

O exemplo da chegada do colonizador à América prova que o corpo foi e é passível de ser docilizado, interditado e punido por aqueles que impõem as ordens e detêm o saber e o poder.

Lembramos também da mulher, visto que sua sexualidade, em muitos momentos da história, foi proibida de se revelar, sendo seu corpo sujeitado e oprimido (Dussel, 1980). Essa violência aparece desde o início da humanidade, de acordo com a tradição vetero-testamentária, quando Eva comeu, e compartilhou com Adão, o Fruto da Árvore do Conhecimento. Há, assim, a partir dessa visão de mundo, justificativas para a submissão do corpo feminino, como encontramos nos capítulos 3 e 4 do livro Gênesis. Nesse trecho do Pentateuco hebraico, ensinado nas "sinagogas" pelos sacerdotes, fazendo parte de uma pedagogia hebraica, e assumido pelos cristãos, na medida em que veem a Bíblia (Antigo e Novo Testamento) como a Palavra de Deus, a mulher não precisa ser criativa e ativa; afinal, ela nada mais é do que reprodutora, sujeitada para ser a esposa e a mãe dedicada do lar. Ela acaba sendo vista como o "sexo frágil", aquele que é fraco, devido à maneira como foi tratada historicamente.

Por conseguinte, essa visão de mundo que nega e interdita homens e mulheres acaba sendo reproduzida e legitimada pela escola. Educadores e educadoras, quando negam seus educandos como sujeitos, "fabricam” objetos para constituir a massa homogênea e padronizada do modo de produção capitalista, para produzir e reproduzir as regras e a cultura imposta pelos dominantes, mantendo o status quo.

Todo processo de negação e interdição do corpo na prática pedagógica só é possível de ser realizado em função do poder disciplinar, tal como foi tratado por Foucault (2009) no livro Vigiar e punir. E a educação bancária, reprodutora do saber, faz uso da vigilância, da punição e do exame. Evidentemente, todo esse processo de proibição do corpo acaba suprimindo a corporeidade e anulando as emoções. Padronizar e massificar homens e mulheres, no contexto econômico, é fundamental para manter o 
andamento do sistema, lembrando que, segundo Foucault (2009), aquele que outrora punia e condenava os culpados (o carrasco) agora é substituído por médicos, psicólogos e, também, por educadores. Dentro das instituições escolares, os educadores acabam sendo os principais responsáveis pela negação dos corpos dos educandos.

Dessa maneira, como escreve Freire (2000, p. 75), estudar o passado é fundamental para trazer à "memória de nosso corpo consciente" o motivo de muitos acontecimentos do presente, para não os repetir, ao mesmo tempo em que se vai além das marcas deixadas. Paulo Freire busca a humanização do sujeito, para superar sua condição e herança histórica de mutismo, assistencialismo e domesticação do corpo, categorias que o autor discute na obra Educação e atualidade brasileira (2003).

Por fim, o objetivo desta pesquisa é identificar o sentido da denúncia da educação bancária, realizada por Paulo Freire e apontar suas implicações para o anúncio de uma educação libertadora sobre o corpo dos educadores. Para responder a essa questão, destacamos alguns elementos, baseados na hermenêutica, que nos auxiliarão nesse caminho, que será o nosso método (metha/odós), isto é, onde pretendemos chegar. Logo, começamos com a exegese do texto até chegar à sua compreensão, que é o nosso objetivo. 0 vocábulo hermenêutica advém do termo grego hermeneuein/hermeneia, que significa "aquilo que é passível de compreensão". Assim, essa vertente epistemológica permite a aproximação do objeto em questão, possibilitando compreender e interpretar a denúncia e o anúncio freireano.

Para isso, apoiamo-nos nos conceitos teóricos do filósofo alemão Hans-Georg Gadamer e do filósofo francês Paul Ricoeur, para dialogarmos com as fontes e o objeto pesquisado. Gadamer (1999) define a hermenêutica como o diálogo com o objeto e com as fontes, de modo que “um diálogo frutífero é um diálogo no qual oferecer e acolher, acolher e oferecer conduz à compreensão e apreensão do objeto (p. 146)”. Ricoeur (1988), ao escrever sobre a tarefa da hermenêutica, define-a como a "teoria das operações da compreensão em sua relação com a interpretação dos textos” (p. 45), observando que ela nos "previne" contra a neutralidade. Aponta, também, que interpretar é "explicitar o tipo de ser-no-mundo manifestado diante do texto" (p. 56).

Portanto, ao identificarmos o discurso emitido nos textos, por meio dos procedimentos metodológicos baseados no método hermenêutico, encontramos nas obras de Paulo Freire reflexões acerca da concepção bancária versus a concepção libertadora de educação, elementos que nos permitiram compreender, apreender e interpretar como ocorre a negação do corpo, especificamente na educação do educador. 


\section{A denúncia da educação bancária como uma negação do corpo}

A concepção bancária de educação nega o diálogo, à medida que na prática pedagógica prevalecem poucas palavras, já que "o educador é o que diz a palavra; os educandos, os que a escutam docilmente; o educador é o que disciplina; os educandos, os disciplinados" (Freire, 2005, p. 68). Desse modo, vemos que o desobediente nunca é o educador, mas, sim, o educando, aquele que precisa ser ensinado a não violar as regras impostas. Entendemos que o professor irá "depositar" (vem daí a ideia de "bancária") os conteúdos em suas cabeças, como se fossem recipientes a serem preenchidos. A educação bancária não é libertadora, mas, sim, opressora, pois não busca a conscientização de seus educandos. Quer, na verdade, que corpos de alunos e alunas sejam inconscientes e sujeitados às suas regras. Perpetua e reforça, assim, sua relação vertical e autoritária.

A prática pedagógica dos educadores é permeada pelo autoritarismo, dizendo aos educandos o que devem fazer e o que responder; portanto, eles vivenciam uma pedagogia da resposta. Não é permitido realizar críticas, assim como não se deve questionar e nem duvidar do professor - aquele que detém o conhecimento e que irá depositá-lo no corpo "vazio" dos alunos. Isso pelo fato de a educação bancária não buscar a conscientização dos educandos. Nesse caso, a educação "é puro treino, é pura transferência de conteúdo, é quase adestramento, é puro exercício de adaptação ao mundo" (Freire, 2000, p. 101).

Podemos definir essa prática de um ensino verbal como uma herança deixada pelos primeiros educadores (os jesuítas), caracterizada pela repetição e pela memorização sem criticidade. É uma educação que valoriza a leitura mecânica, já que, “em lugar de ser o texto e sua compreensão, o desafio passa a ser a memorização do mesmo. Se o estudante consegue fazê-lo, terá respondido ao desafio" (Freire, 2002a, p. 10). Isso se deve ao fato de que a Ordem criada por Inácio de Loyola, cujas ideias iriam ecoar no Concílio de Trento, pretendia reafirmar o medievalismo e propagar as crenças e os dogmas da Igreja Católica que estava, naquele período, sendo desafiada pela Reforma Protestante, diz A. M. Freire (2001). Seus objetivos e suas finalidades estavam fortemente traçados, e os missionários impregnados por essa doutrina não se deixavam abalar pelo que ocorria fora dos bancos escolares. O Ratio Studiorum possuía uma coerência interna, porém, tornava-se incoerente na medida em que suas regras valiam para qualquer aluno em qualquer lugar. Parecia haver uma cisão com a realidade social e política, o que também nos remete ao tipo de educação que temos 
hoje nas escolas, pois o que os professores ensinam aos alunos parece estar distante da realidade deles.

Para Freire (2003), a inexperiência democrática está vinculada diretamente à nossa herança histórica de uma educação de caráter verbal e desumanizante, que é capaz de se sustentar na prática pedagógica até os dias de hoje. Principalmente nas sociedades latino-americanas, que apresentam um sistema educacional precário, as escolas têm o objetivo de manter o status quo, resultando em altas taxas de analfabetismo, diz Freire (2001b). Isso só é possível de continuar ao longo do tempo, devido ao fato de que, segundo Foucault (2010), a dominação deixa marca nos corpos, pois está vinculada a obrigações e direitos. Um professor autoritário e opressor que impõe seu conhecimento, numa relação vertical e não dialógica, desconsidera o meio social e faz com que surjam marcas no corpo do aluno.

Conhecendo um pouco da herança histórica, entendemos o motivo de a instituição escolar não permitir que os corpos se libertem, se humanizem e vivenciem sua condição natural de ser mais. A própria estrutura física da instituição, as cercas, os muros, as posições dos alunos dentro das salas de aulas (cada um em sua carteira enfileirada), a constituição de filas para manter a ordem, o panóptico, como Foucault (2009) descreve, já aguardam os educandos para moldá-los, discipliná-los e dizer a eles como seus corpos devem se comportar. Assim é caracterizado o processo de ensino e aprendizagem. 0 "professor-juiz", citado pelo autor (2009), é um vigilante constante desses corpos, sendo que qualquer desvio poderá levar à punição, seja com suspensões, expulsões ou notas abaixo da média estabelecida.

Em decorrência dessa educação que "dociliza” os corpos dos que se encontram no espaço da instituição escolar, o bom aluno, alerta Freire (2002a), é aquele que reproduz, que não pensa de forma crítica, que apenas se adapta e se acomoda aos

3. Freire (2002a, p. 119) utiliza a expressão "sacralização" para designar algo que não pode ser tocado, nem discutido, e aqueles que assim fazem estão sujeitos a punição. Lembrando que isso acontece dentro da escola, instituição que não permite ser questionada quanto aos seus valores e aos seus princípios. Da mesma forma que a autoridade ou 0 autoritarismo do educador não devem e não podem ser contestados. 0 autor (2002a, p. 147) cita outro exemplo de sacralidade: as sociedades burguesas, já que são contra qualquer tipo de ruptura de seus padrões, que consideram perfeitos. padrões estabelecidos. Por outro lado, o aluno “indisciplinado” é aquele indócil, inquieto, que pergunta, que duvida e que é sujeito, recusando-se a aceitar os modelos existentes. É aquele que pensa sobre sua realidade. 0 professor assume sua função de profissional divino na sacralidade $^{3}$ da instituição escolar, de acordo com o autor. Torna-se um ser intocável, possui- 
dor de uma autoridade incontestável que irá se refletir no corpo do educando. Como, por exemplo, “o aluno não pode, num gesto afetivo, sequer por-lhe a mão no ombro. Esta intimidade de mortais ameaçaria a distância necessária entre ele e os educandos..." (Freire, 2002a, p. 120).

O corpo do indivíduo também é marcado e oprimido na medida em que é massificado, observa Freire (2003), pois ele não assume uma posição crítica perante a vida, sua consciência nada mais é que ingênua. Desse modo, homens e mulheres são passíveis de domesticação, o ser humano não possui mais endereço, torna-se "desenraizado" (Freire, 2003, p. 39). A escola parece assumir esse papel de domesticação dos educandos, tornando dóceis os corpos das crianças, como afirma Foucault (2009). Padronizam-nas durante o processo de ensino, para que assim, fora do ambiente escolar, em outras instituições e na sociedade, elas também continuem perpetuando esse modelo de consciência ingênua e massificada.

Para dar conta dessa massificação e tornar a educação útil ao sistema, a formação/educação dos educadores 4 acaba se tornando um mero treinamento de professores, o que resultará numa prática pedagógica que interdita e também treina os corpos dos estudantes. Freire (2000) diz que o ensino hoje está ligado ao saber técnico. Para tanto, os educandos precisam ser bem "treinados", sendo que a educação apenas “adapta" homens e mulheres ao mundo tal qual se apresenta, caminhando para a despolitização. Por isso, como diz o autor (2000, p. 108), educadores e educadoras não podem se transformar em "educadores pragmáticos".

Por isso, reiteramos em Freire (2005) que o anúncio de uma verdadeira libertação dos homens e a sua humanização não pode ser realizado por meio de “depósitos”, tal qual a educação bancária faz. Deve-se, sim, realizar-se com a práxis: ação e reflexão sobre o mundo. A educação libertadora e problematizadora do sujeito não pode ser a favor de “depósitos” de conteúdos nos corpos "vazios" dos educandos, nem de uma consciência mecanizada. Homens e mulheres precisam ser corpos conscientes. Assim,

a educação libertadora, problematizadora, já não pode ser o ato de depositar, ou de narrar, ou de transferir, ou de transmitir "conhecimentos" e valores aos educandos, meros pacientes,

4. É importante ressaltar que a terminologia freireana não levou em conta, aqui, o sentido originário das palavras, já que "formação" e "formar" nos remetem a dar forma a um corpo amorfo, desestruturado, sendo o professor aquele que precisa colocar os alunos numa forma para padronizá-los, torná-los iguais. Podemos chamar esse processo de interdição pedagógica do corpo. Levando em conta a raiz etimológica, escolhemos as opções "educação" e "educar”, baseando-nos na Terceira tese de Marx sobre Feuerbach: quem educa o educador e, como? Só transcrevemos as palavras "formação" e "formar" quando Freire as utiliza, porém, ele não relacionou "formar" com dar forma. 
à maneira da educação "bancária", mas um ato cognoscente. ... 0 antagonismo entre as duas concepções, uma, a "bancária” [grifos do autor], que serve à dominação; outra, a problematizadora, que serve à libertação, toma corpo exatamente aí. Enquanto a primeira, necessariamente, mantém a contradição educador-educando, a segunda realiza a superação (p. 78).

Para o educador/problematizador os educandos não são seus "recipientes dóceis de depósitos” (Freire, 2005, p. 80), pois, na educação libertadora, eles são investigadores críticos que possuem um diálogo constante com o professor. São vistos como seres reflexivos, críticos e criadores. Portanto, diz o autor, a educação libertadora é diferente de uma educação domesticadora, pois não aceita o homem solto e desligado do mundo, já que a realidade é feita por seus próprios homens. É que "se os homens são estes seres da busca e se sua vocação ontológica é humanizar-se, podem, cedo ou tarde, perceber a contradição em que a 'educação bancária' pretende mantê-los e engajar-se na luta por sua libertação" (p. 71).

Freire (2004) ressalta que, enquanto a educação bancária tem como objetivo realizar uma divisão entre "os que sabem e os que não sabem, entre oprimidos e opressores", negando o diálogo, a educação problematizadora, em contrapartida, "funda-se justamente na relação dialógico-dialética entre educador e educando: ambos aprendem juntos" (p. 69). A libertação acontece por meio de uma educação que desenvolve a consciência e a humanização nos educandos e educadores, possibilitando a superação da opressão, da domesticação e da adaptação.

\section{Superação da negação do corpo: o anúncio da pedagogia libertadora freireana}

Freire contribui com reflexões e práticas acerca da libertação dos [corpos] oprimidos, negados e interditados. Por isso, encontramos presente em suas obras a importância do diálogo, da conscientização, do homem-sujeito, e não do homem-objeto, mas do indivíduo histórico que pode e deve interferir no rumo da sua história. Por exemplo, quando o sujeito é corpo consciente, ele pode recusar a negação e a interdição do seu corpo.

Assim, Andreola (2000), ao comentar sobre o projeto político-pedagógico na pedagogia de Freire, diz que essas ideias estão presentes e foram se construindo ao longo da vida do autor, já que: 
Esta idéia de um novo projeto histórico, para a construção de uma humanidade mais solidária, está presente já na intuição dramática do garoto angustiado de Jaboatão. Aquela idéia crescerá, através dos anos, traduzindo-se, um dia, numa proposta intitulada Educação como prática da liberdade. Irá se explicitando ao longo dos anos, através de diferentes formas de ação e de formulações teóricas. As denominações: ação cultural para a liberdade, educação libertadora, conscientização, pedagogia do oprimido, pedagogia da esperança, expressam, em diferentes formas e em momentos diversos, a idéia básica de uma pedagogia política de libertação (p. 119).

Na visão de Freire (2005), uma pedagogia libertadora precisa ser feita com os oprimidos e não para os oprimidos. Nas salas de aula, por exemplo, o(a) professor(a) deve estar com os(as) educandos(as), aberto e disponível à curiosidade dos alunos; para tanto, não pode assumir uma postura rígida, discorre Freire (2001a). Por isso, a “leitura de mundo" de cada educando é fundamental, pois eles estão cheios de dúvidas e sugestões que trazem da sua realidade, do seu contexto. Claro que a linguagem científica também é importante, mas numa relação dialética com a linguagem do mundo dos educandos. Isso só será viável quando o educador com seu “corpo consciente, sensível, emocionado se abre às adivinhações dos alunos, à sua ingenuidade e à sua criticidade - o ensinante que assim atua tem, no seu ensinar, um momento rico de seu aprender" (p. 28).

E é justamente na sua prática pedagógica libertadora, que o educador pode lutar contra o fatalismo que a sociedade capitalista nos traz, seja contra o desemprego, a miséria ou os altos índices de analfabetismo. A educação não pode ser aquela que deposita, que incentiva a memorização mecânica, a que treina (concepção bancária), porém aquela que ajuda homens e mulheres, sujeitos de sua história, a pensar criticamente, colocando-lhes desafios, dando espaço para mostrar suas curiosidades e suas indagações. Ao contrário da educação bancária, que não busca a conscientização de seus educandos, quer, na verdade, que corpos de alunos e alunas sejam inconscientes e sujeitados às suas regras, perpetuando, assim, sua relação vertical.

Para expulsar a sombra da opressão das camadas mais ingênuas da sociedade, Freire (2009) diz que é preciso conscientizá-las, pois, quando elas são massificadas, tornam-se domesticadas. A conscientização, como diz o autor, é uma tarefa da educação libertadora, que precisa estar vinculada não apenas a uma tomada de consciência da realidade, mas, também, à sua transformação. Veremos, a seguir, o processo 
de conscientização do corpo negado e as implicações da pedagogia libertadora na educação dos(as) educadores(as).

\subsection{Paulo Freire e a conscientização do corpo negado}

Freire (2001b) comenta sobre a origem da palavra conscientização, que não foi criada por ele, mas por um grupo de professores do Instituto Superior de Estudos Brasileiros (ISEB), em 1964, dentre eles o filósofo Álvaro Vieira Pinto e o professor Guerreiro. Diz, ainda, que faz uso desse conceito por acreditar na "profundidade de seu significado”, pois está “absolutamente convencido de que a educação, como prática da liberdade, é um ato de conhecimento, uma aproximação crítica da realidade" (p. 29). Com isso, a conscientização vai além de uma simples apreensão, mas deve alcançar um nível crítico da realidade. E mais,

a conscientização é ... um teste de realidade. Quanto mais conscientização, mais se des-vela a realidade, mais se penetra na essência fenomênica do objeto, frente ao qual nos encontramos para analisá-lo. Por esta mesma razão, a conscientização não consiste em estar frente à realidade assumindo uma posição falsamente intelectual. A conscientização não pode existir fora da práxis, ou melhor, sem o ato ação-reflexão. Esta unidade dialética constitui, de maneira permanente, o modo de ser ou de transformar o mundo que caracteriza os homens (p. 30).

A transitividade da consciência faz com que cada indivíduo vença a falta de comprometimento com a sua existência, característica da consciência intransitiva, que vive um estado quase vegetativo da história. Freire (2009) afirma que o homem se faz histórico quando dialoga com outro homem e com o mundo, sobre seus problemas e seus desafios. Para ele, a passagem da consciência transitivo-ingênua para a transitivo-crítica não acontece naturalmente, mas "somente por efeito de um trabalho educativo crítico com esta destinação. Trabalho educativo advertido do perigo da massificação, em íntima relação com a industrialização, que nos era e é um imperativo existencial” (p. 70).

A conscientização implica num compromisso histórico, à medida que homens e mulheres assumem sua função de sujeitos que interferem no mundo como corpos conscientes. Não há uma dicotomia, mas uma relação consciência-mundo. Outro fator importante levantado pelo autor (2001b) é que para alcançar a conscientiza- 
ção crítica é preciso não apenas o esforço intelectual, mas a práxis, isto é, ação e reflexão.

Freire (2009) torna claro que a transitividade crítica é possível com uma educação dialógica, que interprete os problemas e tenha uma responsabilidade social e política, e que coloque de lado os preconceitos ao analisar os problemas. Isso não acontece numa educação que nega o corpo do outro, incitando-o a uma posição de mutismo. Por isso, diz o autor, uma prática pedagógica crítica, baseada em situações históricas, levará à criticidade.

Na pedagogia da liberdade, Freire (2001b) afirma que a alfabetização tem como objetivo preparar para a democracia, o que não significa apenas transformar o analfabeto em eleitor. Na verdade, prepararia o alfabetizando para realizar seu próprio juízo crítico perante as possibilidades que a elite apresenta e, assim, tomar sua decisão. Portanto, conscientização e alfabetização estão intimamente ligadas, na medida em que a finalidade do indivíduo em tornar-se alfabetizado não é apenas para reconhecer as letras, as sílabas e ter capacidade de ler uma frase. É, também, para tornar-se um sujeito de sua história, engajado nas lutas políticas e culturais. A conscientização do educando, comenta Freire (2002a, p. 72), se torna verdadeira na relação dialética entre teoria e prática, “nesta ida e volta”. Por isso, o autor volta a destacar que o processo de conscientização não ocorre antes ou depois da alfabetização, mas de forma que se dá em ações de educação política com analfabetos durante o processo de alfabetização.

A rigor, quando se faz o anúncio de um mundo melhor não apenas se fala do que pode vir, segundo Freire (2000), mas se fala de como está sendo a realidade. Então, a denuncia, e anuncia o que está por vir. Quando isso não acontece, a educação vira, novamente, um simples treinamento, com regras, técnicas e normas a serem seguidas. No entanto, aqueles que se comprometem com a transformação do mundo são proféticos, pensando na sua condição de ser mais, relata Freire (2001b), já que anunciam e denunciam o meio em que vivem. Diferentemente dos opressores e dos reacionários que não podem ser utópicos, pois a utopia está intimamente ligada à conscientização; “quanto mais conscientizados nos tornamos, mais capacitados estamos para ser anunciadores e denunciadores, graças ao compromisso de transformação que assumimos” (p. 32). Assim, continua o autor, para superar o processo de dominação, o tema da libertação deve substituí-lo e, para isso, homens e mulheres precisam romper com sua posição quietista. 
Portanto, o projeto de conscientização é inviável de ser realizado pela direita, acrescenta Freire (2002a), pois ela, além de não ser utópica, não poderá realizar uma denúncia dos meios opressores. Por outro lado, as camadas oprimidas poderão denunciar e, ao mesmo tempo, anunciar uma nova realidade a partir do seu contexto social e histórico.

Freire (2001b) destaca: “para mim o utópico não é o irrealizável; a utopia não é o idealismo, é a dialetização dos atos de denunciar e anunciar, o ato de denunciar a estrutura desumanizante e de anunciar a estrutura humanizante. Por esta razão a utopia é também um compromisso histórico" (p. 32). Dessa maneira, a conscientização vem assumir esse papel utópico perante o mundo. Quando os indivíduos têm consciência do mundo, têm também consciência de si e veem o mundo como mutável, o que permite que eles não estejam apenas no mundo, mas com o mundo e também com outros sujeitos (Freire, 2000). Freire ainda lembra que homens e mulheres conscientes interferem no mundo, por isso, têm e fazem história, ao mesmo tempo em que são feitos por ela. Uma posição de sectarismo perante o mundo e a si mesmo é inaceitável, já que nega o processo de conscientização do indivíduo. Assim, segundo Freire (2002a):

nem a consciência é exclusiva réplica da realidade nem esta é a construção caprichosa da consciência. Somente pela compreensão da unidade dialética em que se encontram solidárias subjetividade e objetividade podemos escapar ao erro subjetivista como ao erro mecanicista e, então, perceber o papel da consciência ou do "corpo consciente" [grifo do autor] na transformação da realidade (p. 155).

Nesse processo de conscientização do corpo negado, é importante assegurar que o revolucionário ou o educador progressista não irá conscientizar o indivíduo ou o educando-massa. Não irá depositar nos corpos deles uma suposta “conscientização”, pois assim estaria reproduzindo o mecanismo da educação bancária, na qual aquele que detém o poder/saber preenche o corpo vazio dos que nada sabem. Segundo Freire (2002a, p. 162), o partido revolucionário não deve criar "escolas revolucionárias" e, posteriormente, partir para a revolução. 0 autor procura destacar que aqueles que buscam a revolução precisam estar com as massas populares, não as anular ,pois, se assim o fizerem, estarão adotando uma medida mecanicista e não dialética. Por esse motivo é substancial que o educador seja educado. 
Podemos constatar, com as obras de Freire, que homens e mulheres, sujeitos de sua história, se conscientizam entre si, de forma mútua e, consequentemente, interferem e transformam sua história, que não é determinada, mas condicionada. É por meio do "corpo livre e consciente" e por meio de uma ação pedagógica libertadora, que o indivíduo terá consciência do seu corpo negado, aprisionado e interditado. A prática pedagógica libertadora, proposta por Freire, vem para superar essa ação de interdição pedagógica do corpo que tem implicações na educação dos educadores.

\subsection{Pedagogia libertadora e educação do corpo de educadoras e educadores}

A pedagogia libertadora se faz a partir dos oprimidos, dos seus interesses, dos seus conhecimentos, da sua cultura e da sua história. Como vimos anteriormente, o professor não poderá ser autoritário com o corpo dos seus alunos, mas não significa que ele deva ser licencioso, até porque o educador é diferente de seus educandos. Freire mostrou que uma educação desvinculada da classe dominante e do Estado é possível, prova disso foram os círculos de cultura, onde os analfabetos conseguiam aprender a ler e a escrever com temas advindos da sua realidade, podendo o coordenador proporcionar uma discussão e, mutuamente, acontecer o processo de conscientização dos adultos. Gadotti (2004, p. 38) destaca que a originalidade em Freire está na visão que ele tem do processo educacional, que acontece por meio de uma “ótica libertadora”.

Assim sendo, sabendo da importância teórico-prática que tem a obra Pedagogia do oprimido, poderíamos considerá-la como um “ manifesto pedagógico em favor do corpo - uma singularidade no campo da educação naquele momento. Daí teríamos uma Pedagogia do [corpo] oprimido", diz Almeida (2008, p. 105), numa entrevista realizada com Moacir Gadotti sobre corpo e pedagogia em Paulo Freire. Entretanto, Almeida (2008) declara que pode haver um obstáculo nessa hipótese, dada a temática abordada sobre conscientização naquele livro, o que poderia nos distanciar do corpo. Ele diz que essa compreensão nos leva ao que Freire chama de corpo consciente: "por que a libertação, senão para libertar os corpos famintos, os esfarrapados de Fanon e todos os outros, de todos os continentes?" (p. 106).

Uma sociedade democrática não pode ser construída pelas elites, já que elas não oferecem fundamentos para uma política de reformas. Aquele que oprime não quer uma educação libertadora, pois acredita que o educando é objeto e não sujeito. En- 
tretanto, afirma Gadotti (2004), ao falar das obras de Freire, só as massas populares podem lutar para transformar a sociedade. Aqui entra também a educação para proporcionar a conscientização do corpo dos indivíduos. Para Gadotti (2004), o diálogo que vem das elites é vertical, resultando num "educando-massa" que não pode se expressar livremente, apenas ouvir e obedecer. Afinal, seu corpo é interditado pela própria educação: a escola se encarrega dessa finalidade. Portanto, o autor (2004) assevera que, para passar da consciência ingênua para a consciência crítica, é preciso que o educando recuse a hospedagem do opressor no seu corpo. Assim, poderá tornar-se corpo consciente e rejeitar a ideologia da interdição do corpo imposta pelos opressores.

A verdadeira libertação das classes oprimidas, as quais formam um só corpo, se dá não apenas pela libertação mental, dizem Freire e Faundez (1985), mas também pela libertação corporal, física. Sendo que não é somente a sombra, mas também o físico do colonizador que está hospedado no corpo do colonizado, afirma o autor. Freire, nessa mesma obra, responde ao professor chileno, alegando que é justamente a sombra do colonizador que se concretiza no corpo físico e no comportamento do colonizado.

Como, então, se poderia romper a dominação legitimada pelos opressores? Lembremos que, para os oprimidos se libertarem, precisam, primeiramente, conscientizar-se e humanizar seus corpos interditados e, também, os corpos daqueles que os oprimem. Caso contrário, reproduzirão as atitudes do opressor e irão se ajustar à realidade, acreditando que a história não é passível de mudanças, visto que sua condição social já é determinada desde o nascimento. Para provar o contrário, recorremos a Merleau-Ponty (1994), quando afirma que a história não pode ser dada como um processo rígido, nem como “ uma novidade perpétua, nem uma repetição perpétua, mas o movimento único que cria formas estáveis e as dissolve”(p. 130). Logo, ao mesmo tempo em que a história se repete, também cria coisas novas, e aqueles que são sujeitos tomam o rumo de sua história e compreendem a dinâmica de seu movimento dialético. Nesse sentido é que Nóbrega (2007), analisando o pensamento de Merleau-Ponty, diz que o corpo, além de estar tomado pela subjetividade, está também recortado por sua historicidade.

Por conseguinte, para o movimento de libertação dos oprimidos se concretizar, a partir de um processo político-pedagógico, os opressores também precisam ser libertados: 
Somente os oprimidos podem libertar os seus opressores, libertando-se a si mesmos. Eles, enquanto classe opressora, não podem nem libertar-se, nem libertar os outros. É, pois, essencial que os oprimidos levem a termo um combate que resolva a contradição em que estão presos, e a contradição não será resolvida senão pela aparição de um homem novo [itálico do autor]: nem o opressor, nem o oprimido, mas um homem em fase de libertação. Se a finalidade dos oprimidos é chegar a ser plenamente humanos, não a alcançarão contentando-se com inverter os termos da contradição, mudando somente os pólos. Para o opressor, a consciência, a humanização dos outros, não aparece como a procura da plenitude humana, mas como uma subversão (Freire, 2001b, p. 69).

O silêncio (histórico) imposto de cima para baixo impede a indagação, a manifestação das dúvidas e da curiosidade. Como dizem Freire e Faundez, (1985): “um dos pontos de partida para a formação de um educador ou de uma educadora, numa perspectiva libertadora, democrática, seria essa coisa aparentemente tão simples: o que é perguntar?” (p. 47). O próprio corpo faz perguntas corporais, com os gestos, na vida diária, assevera Antonio Faundez, na mesma obra.

Ao se conscientizarem, homens e mulheres poderão fazer suas próprias escolhas e interferir na sua história, entendendo que não existem fatalidades, mas condições histórico-sociais que vão se construindo ao longo do tempo. Dessa maneira, para superar uma educação opressora, é fundamental uma educação que prepare “ o homem para isso por meio de uma educação autêntica: uma educação que liberte, que não adapte, domestique ou subjugue. Isto obriga, a uma revisão total e profunda dos sistemas tradicionais de educação, dos programas e dos métodos” (Freire, 2001b, p. 45). Uma educação libertadora não pode valorizar assuntos com palavras alienadas, mas precisa estabelecer uma “aprendizagem para nomear o mundo o processo de alfabetização como ação cultural para a liberdade é o ato de um sujeito cognoscente em diálogo com o educador [itálicos do autor]” (pp. 87-88).

Caso contrário, quando esse diálogo não acontece, o educando é um ser passivo, sendo coisificado por aquele que o educa (ou oprime). Contudo, os educadores que trabalham com uma concepção de educação como prática da liberdade poderão marcar o corpo do seu educando com aspectos positivos, tendo "clareza e consciência de que o corpo que marcam possui vida própria e que, portanto, não lhe pertence, percebem o educando como sujeito que tem voz, pensamento e desejos próprios", aponta Dowbor (2008, p. 72), no livro Quem educa marca o corpo do outro. 
Gadotti (2004) realiza, no final do seu livro Convite à leitura de Paulo Freire, uma conversa com Freire sobre as perspectivas da educação para o final do século XX. Ele relata que a educação nesse período está surgindo com jovens que tiveram sua infância reprimida pela Ditadura. E que esses mesmos educadores falam muito em "vida, singularidade, corpo" (p. 139), de modo que são tomados por uma preocupação com o corpo. Segundo o autor, as gerações passadas lutavam por uma libertação mais social, e as atuais são mais corporais. Isto é, o jovem hoje busca uma libertação que seja permeada pelo prazer, pelo amor, o que só é possível com o corpo. Portanto, ele salienta que a pedagogia de Freire tem enfatizado a pessoa, aquilo que é singular, resgatando o indivíduo na medida em que considera como fundamental a participação de cada um na transformação da história.

Em seguida, Freire (2004), nessa mesma conversa, destaca a importância do papel do corpo. Por que, afinal, o fenômeno "corpo" é importante? Para o autor, o corpo

é o que eu faço, quer dizer, o que eu faço, faz meu corpo. ... A importância do corpo, então, é indiscutível; o corpo atual memoriza a luta de sua libertação, o corpo afinal deseja, aponta, anuncia, protesta, se curva, se ergue, desenha e refaz o mundo. Nenhum de nós, nem tu, nem eu, estamos aqui dizendo que a transformação se faz através de um corpo individual. Não, porque o corpo também se constrói socialmente [itálico do autor] (p. 140).

Outro aspecto essencial levantado por Freire (2004), ainda nessa entrevista, é a relação opressor/oprimido, professor/aluno. 0 educador pernambucano se diz "cheguevariano", pois acredita que o amor e a revolução caminham juntos. Para ele há um sensualismo que é inerente ao próprio corpo e que, ao mesmo tempo, se vincula à capacidade cognoscente. Assim, saber o mundo também implica num modo apaixonado de sabê-lo, ou seja, o ato cognoscente e o amoroso estão entrelaçados dialeticamente, e não divididos de maneira maniqueísta.

A amorosidade precisa estar presente no corpo, na educação dos educadores, presente na sua prática pedagógica. Segundo Freire (2001b), o educador humanista revolucionário precisa, junto com os alunos, empreender uma ação crítica e de humanização, propiciando uma relação de diálogo. Para esse processo se efetivar, é fundamental colocar-se no mesmo nível de relações com os educandos (posição horizontal e não vertical). Num outro sentido, a educação bancária se estabelece por 
uma contradição professor-aluno que deposita, domestica e prescreve o corpo do educando. Para o autor (2001b), a educação crítica leva em conta o potencial criador dos homens, vendo-os como seres inacabados e inconclusos.

No processo de ensino e aprendizagem, o educador problematizador/libertador precisa trabalhar a favor de uma pedagogia da pergunta e não de uma pedagogia da resposta, essa característica da educação bancária visa depositar no corpo "vazio" dos educandos o conteúdo a ser apreendido. Parece, segundo Freire e Faundez (1985), que o aluno e o professor não sabem a importância das perguntas, as quais surgem pelo que Freire chama de "curiosidade". O professor deveria ensinar seu educando a perguntar, ou melhor, possibilitar e oferecer esse espaço para seu corpo irrequieto, mas, na verdade, nem ele foi educado para isso. Daí a importância de uma educação libertadora para que educandos e educadores, juntos, se libertem.

Contudo, Freire e Faundez (1985) dizem que a proibição da pergunta expressa uma proibição maior, reprimindo o indivíduo de expressar-se nas suas relações no mundo e com o mundo. Por isso, Gadotti (2004) diz que a pedagogia da pergunta é também uma pedagogia do oprimido, que pode ser vivenciada na escola e na luta política, na medida em que é contra o autoritarismo e o liberalismo conservador.

Por fim, entendemos que há uma interdição do corpo do educando que se inicia pela proibição da palavra e se estende ao seu comportamento, às suas emoções e ao seu modo de ser no mundo. A prática pedagógica de educadores e educadoras está permeada pela docilização do corpo dos educandos, portanto, dos futuros educadores.

O corpo é também amor, paixão, alegria, saber e sensualismo. Por isso, Freire (2004, ) descreve que os jovens que o leem hoje vão construir não uma pedagogia da licenciosidade, mas uma "pedagogia do contentamento", que propiciará "[...] a tarefa da liberdade, a tarefa da libertação, a história como possibilidade, a compreensão do corpo consciente e sensual, cheio de vida”(p. 141). A educação que visa à libertação não transfere conhecimento, mas implica no próprio ato de conhecer, sendo possível que educandos sejam educadores, e educadores sejam educandos. Isto é, sejam corpos conscientes, humanizados e críticos na investigação e na pesquisa de novos conhecimentos, observa Freire (2002a).

Assim, para que estejam sempre permeados pelo processo de conscientização na prática pedagógica libertadora, é necessário que educandos e educadores sejam corpos conscientes de sua realidade e resistam de maneira crítica à docilização e à 
interdição de seus corpos pela educação bancária. E, desse modo, educador e educando possam fazer sua própria história e, juntos, interferir e transformar seu mundo, à medida que compreendem que são seres condicionados, mas não determinados.

\section{Considerações finais}

Como foi possível perceber, o corpo é negado quando é negada sua humanização e sua condição de ser mais. Logo, é visto apenas como objeto e não como sujeito. É, na verdade, um corpo proibido de ser e de se expressar como deseja, pois segue as regras impostas sem questionar, conforme aprendeu na escola, por exemplo. É dentro da instituição escolar que a cultura dominante é legitimada, ao mesmo tempo em que as outras são excluídas. Podemos afirmar que os indivíduos pertencentes à cultura dos menos favorecidos passam pela experiência da interdição, da proibição do corpo, no momento em que são “domesticados” por aqueles que fazem parte da classe dominante.

O movimento de interdição do corpo acontece quando não se levam em conta as vivências dos educandos, interdita-se o corpo do outro quando não se considera a sua história e lhe impõe uma outra cultura ou saber como "verdadeiro", tentando anular o que já possui. O indivíduo não se expressa pela palavra, porque, muitas vezes, não lhe é permitido, em nossa sociedade até hoje caracterizada pela ausência de diálogo. E a escola, que reproduz a sociedade em si, cumpre o seu papel de reprodutora do status quo. Um exemplo dessa negação pedagógica do corpo, a partir da cultura, é a relação professor x aluno. Aquele detém o saber e passará adiante seus conhecimentos aos educandos, que, na sua visão, nada sabem e devem apenas receber e arquivar os saberes. A esse tipo de relação, Freire (2005), como já discutimos, chama de educação bancária, na sua obra Pedagogia do oprimido.

A instituição escolar acaba reforçando uma prática pedagógica de negação do corpo do educando, já que possui a tarefa de inculcar os valores dados como legítimos nos alunos, numa relação autoritária. E, educandos dóceis, se submetem à prática pedagógica sem contestar, sem oferecer resistência ao autoritarismo ou à cultura de que a escola é transmissora. Sendo legitimadora dessa violência, a escola vai deixando marcas no corpo dos alunos, e isso irá se refletir na prática pedagógica dos educadores dos futuros educadores.

Manter educandos e educadores não politizados ajuda na solidificação de seus corpos inconscientes e na perpetuação da educação bancária, que usa do poder dis- 
ciplinar para ter corpos de educandos dóceis e interditados. Sem contar que os corpos dos educandos continuam colonizados, quando não refletem a educação que recebem verticalmente, quando os educadores veem o educando como um recipiente vazio e pronto a receber conhecimentos determinados, vindos prontos desde os "gabinetes". O corpo continua negado, dócil e interditado, quando não percebe que vive no contexto do modo de produção capitalista que exige pessoas disciplinadas, saudáveis e ativas, não por acreditar no potencial do ser humano, mas por buscar, constantemente, sua produtividade e lucro..

Neste artigo, procuramos, após a denúncia do corpo negado na educação bancária, desenvolver, com Freire, o anúncio da pedagogia libertadora que envolve o processo de conscientização e humanização. A consciência em Freire é o próprio corpo, corpo consciente e sujeito de sua história. Isso significa que ele reflete e interfere nela, transformando-a (práxis). Podemos afirmar, então, lembrando Freire (2005) que, a partir do momento em que o corpo do educador/educando oprimido se conscientiza, ele consegue reconhecer o opressor que nele se hospeda. Conhece assim o motivo de não reproduzir na sua prática pedagógica uma pedagogia da resposta, mas buscar uma pedagogia da pergunta: problematizadora e libertadora.

À guisa de conclusão, compreendemos que a docilização/interdição dos corpos, que começou com os jesuítas, no Brasil, deixou uma herança que se reproduz até os dias de hoje, docilizando os educandos para torná-los iguais e úteis, fazendo uso da punição para normalizá-los. Punição que aparece por meio, não somente dos "exames", das "avaliações", das "provas", mas também da verdadeira "violência simbólica" perpetrada pelos professores sobre os corpos dos alunos. Como diz Mesquida (2012), “professor é aquele que tem uma fé que não é dele (fide - pro), sendo, por isso mesmo, reprodutor de um conhecimento que não produziu; aluno é aquele que não tem luz própria, portanto passivo, um vaso a ser enchido ou um banco no qual é depositado o conhecimento". 


\section{Referências bibliográficas}

Almeida, D. D. M. de. (2008, jan./jun.). Corpo e pedagogia em Paulo Freire: uma conversa inicial com Moacir Gadotti. Revista educação e linguagem, 11(17).

Andreola, B. (2000). Os pressupostos teórico-filosóficos do pensamento de Paulo Freire: o projeto político-pedagógico formulado na pedagogia libertadora. In S. Ventorim, M. F. C. Pires, \& M. C. de Oliveira (Orgs.), Paulo Freire: a práxis político -pedagógica do educador. Vitória: Editora EDUFES.

Dowbor, F.F. (2008). Quem educa marca o corpo do outro. S. L. de Carvalho, \& D. A. Luppi (Orgs.). São Paulo: Cortez.

Dussel, E. (1980). Liberación de la mujer y erótica latinoamericana. Bogotá: Editorial Nueva América.

Foucault, M. (2009). Vigiar e punir: nascimento da prisão. Rio de Janeiro: Vozes.

Foucault, M. (2010). Microfísica do poder. Rio de Janeiro: Edições Graal.

Freire, A. M. A. (2001). Analfabetismo no Brasil: da ideologia da interdição do corpo à ideologia nacionalista, ou de como deixar sem ler e escrever desde as Catarinas (Paraguaçu), Filipas, Madalenas, Anas, Genebras, Apolônias e Grácias até os Severinos. São Paulo: Cortez.

Freire, P. (1992, jan./fev./mar.). Memória: Entrevista Paulo Freire. Entrevista concedida a Mario Sérgio Cortella e Paulo de Tarso Venceslau. Teoria e debate, Fundação Perseu Abramo, (17). Retirado em 28 de agosto de 2010, de <http://www2.fpa. org.br/o-que-fazemos/editora/teoria-e-debate/edicoes-anteriores/memoria-entrevista-paulo-freire $>$.

Freire, P. (2000). Pedagogia da indignação: cartas pedagógicas e outros escritos. São Paulo: Editora UNESP, 2000.

Freire, P. (2001a). Professora sim, tia não: cartas a quem ousa ensinar. São Paulo: Olho d'água.

Freire, P. (2001b). Conscientização: teoria e prática da libertação: uma introdução ao pensamento de Paulo Freire. São Paulo: Centauro.

Freire, P. (2002a). Ação cultural para a liberdade. São Paulo: Paz e Terra.

Freire, P. (2002b). Pedagogia da autonomia. São Paulo: Paz e Terra.

Freire, P. (2003). Educação e atualidade brasileira. São Paulo: Cortez, Instituto Paulo Freire.

Freire, P. (2004). Entrevista com Paulo Freire: a educação neste fim de século. In M. Gadotti, Convite à leitura de Paulo Freire. São Paulo: Scipione. 
Freire, P. (2005). Pedagogia do oprimido. Rio de Janeiro: Paz e Terra.

Freire, P. (2009). Educação como prática da liberdade. Rio de Janeiro: Paz e Terra.

Freire, P., \& Faundez, A. (1985). Por uma pedagogia da pergunta. Rio de Janeiro: Paz e Terra.

Gadamer, H.G. (1999). Verdade e método. Petrópolis: Vozes.

Gadotti, M. (2004). Convite à leitura de Paulo Freire. São Paulo: Scipione.

Merleau-Ponty, M. (1994). Fenomenologia da percepção. São Paulo: Martins Fontes.

Mesquida, P. (2012). Metafísica e educação ou a formação de papagaios. Curitiba: Pucpr (texto de circulação interna).

Nóbrega, T. P. da. (2007). Merleau-Ponty: o corpo, o filósofo e o mundo de toda a gente! In Anais do XV Congresso Brasileiro de Ciências do Esporte, II Congresso Internacional de Ciências do Esporte - CONICE, Recife, PE. Retirado em 26 de setembro de 2011, de <http://www.cbce.org.br/cd/resumos/129.pdf>

Pestalozzi, J. H. (2009). Écrits sur la méthode. Vl. III. Le Mont Sur Lausanne: Ed. Loisirs et Pédagogie.

Plutarchius, L. M. (1844). Oeuvres morales. Paris: Lefreuvre Éditions.

Ricoeur, P. (1988). Interpretação e ideologias. Rio de Janeiro: Francisco Alves.

Submetido à avaliação em 23 de março de 2015; aceito para publicação em 28 de maio de 2015. 
